\title{
Malignant melanoma: diagnosis, treatment and cancer stem cells
}

\author{
Minireview \\ Z. KOZOVSKA*, V. GABRISOVA, L. KUCEROVA \\ Cancer Research Institute BMC SAS, Bratislava, Slovakia \\ ${ }^{*}$ Correspondence: zuzana.kozovska@savba.sk
}

Received February 5, 2016 / Accepted April 1, 2016

\begin{abstract}
Malignant melanoma represents a neoplasm stemming from melanocytes or the cells that develop from melanocytes. Melanocytes, pigment-producing cells, arise from the neural crest and migrate to their final destinations in the skin, uveal tract, meninges, and mucosa. Most melanocytes are found at the epidermal-dermal junction of the skin, and the vast majority of melanocytes arise from cutaneous sites. Cancerous growths develop when unrepaired DNA damage to skin cells (most often caused by ultraviolet radiation from sunshine or tanning beds) triggers mutations (genetic defects) that lead the skin cells to multiply rapidly and form malignant tumours. Malignant tumours consist of heterogeneous populations of tumour cells. Cancer stem cells (CSC) represent a population of cells within a tumour with highly tumorigenic and chemoresistant properties. These cells may be identified by the expression of CSC markers and also by functional assays as tumour-initiating properties in vivo, high aldehyde dehydrogenase activity tested by Aldefluor assay. There are several key stem cells markers specified for malignant melanoma: CD20, CD133, ABCB5, CD271 and ALDH1A. The review provides a detailed overview of risk factors, diagnosis, treatment possibilities and specific properties of cancer stem cells in malignant melanoma.
\end{abstract}

Key words: malignant melanoma, cancer stem cells markers, aldehyde dehydrogenase ALDH1

\section{Epidemiology and risk factors}

Trends indicate that the incidence of melanoma continues to increase, particularly in individuals over 65 years. Additionally, recent data demonstrate a real increase for both males and females, including young women [1]. There are four major types of melanoma, which account for almost $100 \%$ of diagnosed cases: superficial spreading melanoma, nodular melanoma, lentigo malignant melanoma, acral lentiginous melanoma [1].

- Superficial spreading melanoma is the most common type, accounting for $70 \%$ of all melanomas. It is usually flat and irregular in shape, multicoloured, with different shades of black and brown.

- Nodular melanoma tends to develop quite quickly if it is not removed. It begins to grow downwards, deeper into the skin. There is often a raised area on the skin surface with this type of melanoma. Nodular melanomas are often very dark brownish black, or black, in colour.
- Lentigo malignant melanoma develop from very slow growing pigmented areas of skin and are most common in elderly people. They appear in areas of skin that get a lot of sun exposure. It may gradually get bigger over several years and may change shape. If it becomes a lentigo malignant melanoma, it starts to grow down into the deeper layers of the skin and may form lumps (nodules).

- acral lentiginous melanoma is rare and is most commonly found on the palms of the hands and soles of the feet or around the big toenail. It can also grow under the nails.

Although the etiology of melanoma is unknown, casecontrol studies have identified a number of characteristics present in populations at high risk for developing melanoma [2]. These include:

- ultraviolet light: duration of exposure to mainly UV-B radiation 
- exposure to sunlight: acute, intense and intermittent exposure, history of severe blistering sunburn

- exposure during childhood: vulnerability to UV radiation early in life; multiple studies show association between childhood exposure to sunlight and melanoma risk in adults

- the use of a sunbed: the use of a sunbed more than 10 times per year is associated with a doubling in the risk of melanoma

- fair complexion: individuals with red or blond hair and fair skin with freckles and nevi, who do not tan well and burn easily even after minimal exposure

- prior personal and family history: familial human melanoma is characterised by an increased risk of developing a primary tumor, a higher incidence of multiple primary tumors, and an earlier age at onset

- specific genetic conditions: xeroderma pigmentosum, retinoblastoma. [1-3].

\section{Symptoms, diagnosis, staging}

Cutaneous melanoma can occur anywhere in the body. Clinical features of melanoma include irregular raised surface, asymmetrical shape, irregular perimeter, variegated colour, changing appearance, surface ulcerations, bleeding, inflammation, itching and pain [1]. The ABCDE rule can be used to distinguish between benign and malign lesions and if you see one or more there is a warning sign for melanoma.

- Asymmetry: the shape of one half does not match the other half

- Border that is irregular: the edges are often ragged, notched, or blurred in outline; the pigment may spread into the surrounding skin

- Colour that is uneven: shades of black, brown, and tan may be present; areas of white, grey, red, pink, or blue may also be seen

- Diameter: there is a change in size, usually an increase; most of the melanomas are larger than 6 millimeters

- Evolving: the mole has changed size, shape, colour, has risen or scabbed over the past few weeks or months $[4,5]$

To confirm the diagnosis of the disease, histological examination is performed. The tumor, nodes, metastases (TNM) system of American Join Committee of Cancer (AJCC) is used for melanoma staging.

- Stage $\mathbf{0}$ - the melanoma is in situ, meaning that it is in the epidermis but has not spread to the dermis.

- Stage IA - the melanoma is less than $1.0 \mathrm{~mm}$ in thickness. It is not ulcerated and has a mitotic rate of less than $1 / \mathrm{mm}^{2}$. It has not been found in lymph nodes or distant organs.

- Stage IB - the melanoma is less than $1.0 \mathrm{~mm}$ in thickness and is ulcerated or has a mitotic rate of at least $1 / \mathrm{mm}^{2}$, or it is between 1.01 and $2.0 \mathrm{~mm}$ and is not ulcerated. It has not been found in lymph nodes or distant organs.

- Stage IIA - the melanoma is between $1.01 \mathrm{~mm}$ and $2.0 \mathrm{~mm}$ in thickness and is ulcerated, or it is between 2.01 and
$4.0 \mathrm{~mm}$ and is not ulcerated. It has not been found in lymph nodes or distant organs.

- Stage IIB - the melanoma is between $2.01 \mathrm{~mm}$ and $4.0 \mathrm{~mm}$ in thickness and is ulcerated, or it is thicker than $4.0 \mathrm{~mm}$ and is not ulcerated. It has not been found in lymph nodes or distant organs.

- Stage IIC - the melanoma is thicker than $4.0 \mathrm{~mm}$ and is ulcerated. It has not been found in lymph nodes or distant organs.

- Stage IIIA - The melanoma can be any thickness, but it is not ulcerated. It has spread to 1 to 3 lymph nodes near the affected skin area, but the nodes are not enlarged and the melanoma is found only when they are viewed under the microscope. There is no distant spread.

- Stage IIIB - The melanoma can be any thickness and is ulcerated. It has spread to 1 to 3 lymph nodes near the affected skin area, but the nodes are not enlarged and the melanoma is found only when they are viewed under the microscope. There is no distant spread.

- Stage IIIC - The melanoma can be any thickness and is ulcerated. It has spread to 1 to 3 lymph nodes near the affected skin area. The nodes are enlarged because of the melanoma. There is no distant spread.

- Stage IV - The melanoma has spread beyond the original area of skin and nearby lymph nodes to other organs such as the lung, liver, or brain, or to distant areas of the skin, subcutaneous tissue, or distant lymph nodes. Neither spread to nearby lymph nodes nor thickness is considered in this stage, but typically the melanoma is thick and has also spread to the lymph nodes [6].

\section{Oncogenic alterations in melanoma}

Melanoma is not a homogenous disease but instead is composed of biologically distinct subtypes. Evidence is accumulating that the underlying genetic alterations drive the observed morphologic (phenotypic) variation among melanomas [1]. Mutation in the BRAF gene was discovered to play a significant role in development of melanoma. RAF proteins are a family of protein-serine/threonine kinases. Oncogenic mutations in BRAF lead to constitutive activation of the RAS/ RAF/MEK/ERK pathway, a signal transduction cascade that participates in the regulation of a large variety of processes including apoptosis, cell cycle progression, differentiation, proliferation, and transformation to the cancerous state [7]. MEK proteins are upstream regulators of the ERK pathway, which promotes cellular proliferation. BRAF V600E mutations result in constitutive activation of the BRAF pathway, which includes MEK1 and MEK2. BRAF isoform was found to be mutated in nearly $70 \%$ of melanomas. Over $90 \%$ of all BRAF mutations in melanoma are caused by a glutamicacid-for-valine substitution at position 600 (V600E). Other mutations, including NRAS, c-KIT, AKT and GNAQ have also been identified among patients with melanoma[8-10]. The identification of BRAF V600 somatic mutations in melanoma 
[11] led to the development of molecularly targeted therapies, which improved the prognosis of metastatic melanoma patients compared to chemotherapy [12-14].

\section{Malignant melanoma CSC}

Malignant tumors consist of morphologically and functionally heterogeneous population of cells [15]. Cancer stem cell theory says that only a minority of tumor cells, so called cancer stem cells (CSC), has the exclusive property of driving the growth and spread of a tumor [16]. CSC are potentially tumorigenic and chemoresistant through their relative quiescence, $\mathrm{ABC}$ transporter expression, dysregulation in apoptotic signalling, and their capacity for DNA repair. They also demonstrate self-renewing abilities and differentiation capacity $[17,18]$. CSC niche is the specific microenvironment in which CSCs grow and it is of a great clinical potential for development of novel therapeutic strategies selectively target CSCs and their micro environmental niche [19].

In most tissues in which cancer originates, stem cells have the longest life span and therefore they are exposed to more genotoxic stresses than their shorter-lived, differentiated progeny. This quiescence and dormancy protect CSC population from genotoxic stress and also from high rate of DNA damage and repair [20-22].

In addition, CSC share the expression of some markers with normal stem cells, therefore, it was originally postulated that cancer stem cells arose from normal stem cells [23]. Several recent studies now entertain the possibility of "tumor cell plasticity", where non-CSC can dedifferentiate and acquire CSC-like properties under certain conditions $[24,25]$.

Malignant melanoma CSC may be identified by the expression of CSC markers and also by functional assays as tumor-initiating properties in vivo, high aldehyde dehydrogenase activity tested by Aldefluor assay. There are several key stem cells markers specified for malignant melanoma: CD20 [26], CD133 [27], ABCB5 [28], CD271 [29] and ALDH1A [30]. It was demonstrated that human metastatic melanoma cells were able to self-renew in vitro and in vivo, retained multipotent potential, grew as spheroid cells, and were enriched for tumor-forming potential. Melanoma sphere-forming cells did not demonstrate CD133 expression; however, melanoma spheroid cells initiated tumor growth in vivo and CD20+ cells proliferated to give larger spheres than CD20 - cells. In another study, drug efflux transporter ABCB5 was found to be specifically expressed on CD133+ tumors cell phenotype-expressing subpopulations within clinical human malignant melanomas of both primary and metastatic origin [28, 31]. Later study identified CD $271+$ cells as melanoma stem cells $[29,32]$ and the most recent study showed that human malignant melanoma CSC possess high aldehyde dehydrogenase (ALDH) activity with ALDH1A1 and ALDH1A3 being the predominant ALDH isozymes. The ALDH-positive melanoma cells were more tumorigenic and more resistant to chemotherapeutic agents than ALDH-negative cells and ALDH1A silencing led to cell cycle arrest, apoptosis, decreased cell viability in vitro, reduced tumorigenesis in vivo and sensitized melanoma cells to druginduced cell death [33]. A number of recent studies propose an important role of ALDH1A1 in the response to chemotherapy of patients with colon cancer $[22,34]$ or other neoplasia. The ALDH1A1 is also associated with worse progression-free survival and overall survival in clear cell renal cell carcinoma [35] and breast cancer patients treated with neo-adjuvant chemotherapy [36]. Moreover, ALDH1A1 expression associates with chemoresistance of cultured and xenografted ovarian cancer and pancreatic adenocarcinoma cells $[37,38]$. Likewise, gastric cancer cells with high level of ALDH1A1 expression are more resistant to 5-FU and cis-diamminedichloroplatinium than those cells with lower level [39].

Long-term-melanoma growth depended on the expression of the histone 3K4 demethylase JARID1B/KDM5B. Roesch et. al. [40] identified a subpopulation of melanoma cells with high levels of JARID1B expression, themselves characterized by slow proliferation but still able to initiate rapidly proliferating cellular progeny. Stable knockdown of JARID1B- in long-term cultures and serial xenotransplantation experiments resulted in cessation of melanoma growth. Unexpectedly, JARID1B-negative cells turned JARID1B-positive depending on environmental conditions (for example, hypoxia) [40]. However, there might be also other mechanisms which regulate cancer stem cells in melanoma, e.g. metabolic regulation and epithelial-mesenchymal transition [41-43]. Our unpublished data indicated that there was very high plasticity among the melanoma cells and the tumor initiating capabilities were induced by alteration in their metabolic state (manuscript under revision).

\section{Treatment}

Surgical resection is the primary treatment of all stages of melanoma. Removal of the tumor can be performed as local excision, wide local excision, lymphadenectomy or sentinel lymph node biopsy [44]. Histologic verification of the diagnosis is essential before embarking upon any treatment plan. Micro staging of the primary lesion can identify patients who have an increased probability of harbouring microscopic metastatic disease [45]. These are the patients who most likely benefit from lymph node dissection. Adjuvant therapy is recommended to some patients with stage II and patients with stages III and IV. However, the chemotherapy drugs now being used are of limited value in most people with stage IV melanoma. Due to poor prognosis associated with this disease, entry into a clinical trial is the preferred first line of treatment (NCCN Clinical Practice Guidelines in Oncology - NCCN Guidelines ${ }^{\oplus}$, version 3.2015). Treatment regimens are described in the table 1 below.

\section{Adjuvant treatment of advanced or metastatic melanoma}

Adjuvant therapy includes:

- immunotherapy: melanoma vaccines, interferons (IFN alfa-2), IL-2 
- radiation therapy

- chemotherapy

- biochemotherapy: combination of chemotherapy with cytokine therapy [46].

Following drugs are approved to be administered as an adjuvant therapy to patients with melanoma [47]

\section{Aldesleukin}

Aldesleukin is recombinant IL-2 approved to treat metastatic melanoma. It acts as a regulator of the immune response. The exact mechanism by which aldesleukin-mediated immunostimulation leads to antitumor activity is not yet known [47].

\section{Recombinant interferon alfa- $2 b$}

Recombinant interferon alfa- $2 \mathrm{~b}$ is mainly used in patients, who are at high risk of systemic recurrence after surgery, e.g., patients with primary or recurrent lymph node involvement. It exhibits antiproliferative effects including suppression of cell proliferation and such immunomodulating activities as enhancement of the phagocytic activity of macrophages and augmentation of the specific cytotoxicity of lymphocytes for target cells [48].

\section{Peginterferon Alfa- $2 b$}

Peginterferon alfa- $2 \mathrm{~b}$ is indicated for the adjuvant treatment of melanoma with microscopic or gross nodal involvement within 84 days of definitive surgical resection including complete lymphadenectomy. It is a pleiotropic cytokine. IFNPEG- $2 b$ is characterized by the incorporation of a polyethylene glycol molecule (pegylation) to IFNa-2 $\beta$, which makes it larger and decreases its metabolism, with the benefit of prolonging plasma concentration [49].

\section{Dabrafenib, Vemurafenib}

These inhibitors of RAF kinases are indicated for the treatment of adult patients with unresectable or metastatic melanoma with a BRAF V600 mutation [50, 51].

\section{Trametinib}

Trametinib is indicated for the treatment of patients with unresectable or metastatic melanoma with BRAF V600E or V600K mutations. It is a reversible inhibitor of MEK1 and MEK2 activation and of MEK1 and MEK2 kinase activity [52].

\section{Selumetinib and Cobimetinib}

Selumetinib, a highly selective MEK $1 / 2$ inhibitor, has been tested in order to assess its efficacy and safety profile in
Table 1. Malignant melanoma treatment regimens, according [67].

\begin{tabular}{ll}
\hline Stage & Treatment \\
\hline 0 + IA & $\begin{array}{l}\text { Wide-excision surgery and discussion of sentinel lymph node } \\
\text { biopsy (SLNB) }\end{array}$ \\
\hline IB + IIA & SLNB and wide-excision surgery \\
\hline IIB + IIC & $\begin{array}{l}\text { SLNB and wide-excision surgery, } \\
\text { if a node is positive - complete dissection of nodal basin, } \\
\text { optional: adjuvant therapy - interferon alfa }\end{array}$ \\
\hline III & $\begin{array}{l}\text { Surgical excision with complete lymph node dissection, } \\
\text { adjuvant therapy: clinical trials or observation or interferon } \\
\text { alfa, optional: radiation therapy }\end{array}$ \\
\hline IV & $\begin{array}{l}\text { Depends on whether melanoma is limited (resectable) or dis- } \\
\text { seminated (unresectable) }\end{array}$ \\
& $\begin{array}{l}\text { Limited: resection, treatment includes clinical trials or systemic } \\
\text { therapy, then assessment for response, if stable - treatment } \\
\text { continues } \\
\text { Disseminated: without brain metastases - systemic therapy, } \\
\text { if brain metastases are present - treatment of the central } \\
\text { nervous disease }\end{array}$ \\
\hline
\end{tabular}

numerous studies associated with various types of tumors. The combinations of selumetinib and different chemotherapeutic agents including irinotecan, docetaxel, temozolomide and doxorubicin showed the enhanced activity against tumor cells in malignancies such as BRAF-mutant melanoma [53]. Another noncompetitive inhibitor, highly specific for MEK1 and 2 kinases is a cobimetinib [54].

\section{Ipilimumab}

Ipilimumab is a fully human recombinant anti-CTLA-4

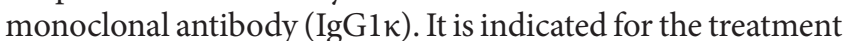
of advanced melanoma in adults. CTLA-4 is a negative regulator of T-cell activation. Ipilimumab is a T-cell potentiator that specifically blocks the inhibitory signal of CTLA-4, resulting in T-cell activation, proliferation, and lymphocyte infiltration into tumors, leading to tumor cell death. The mechanism of action of ipilimumab is indirect, through enhancing T-cell mediated immune response [55].

\section{Tremelimumab}

Tremelimumab is a CTLA- 4 blocking antibody. In phases I and II of the studies of tremelimumab there has been a promising response in patients under treatment. The response rates were similar to ipilimumab and could be observed in about $10 \%$ of patients [56].

\section{Pembrolizumab}

Pembrolizumab (previously known as MK-3475 and lambrolizumab) is a potent, highly selective, fully humanized immunoglobulin (Ig) G4-kappa monoclonal antibody against PD-1. It is suitable for the treatment of patients with 
unresectable or metastatic melanoma with disease progression following ipilimumab, and if BRAFV600 mutation positive. Pembrolizumab has also demonstrated efficacy in other advanced in solid tumors and hematologic malignancies [57].

\section{Dacarbazine}

Dacarbazine is indicated for the treatment of patients with metastasized malignant melanoma. It is a prodrug converted by demethylation to cytostatic agent. The antineoplastic effect is due to an inhibition of cell growth and DNA synthesis. An alkylating effect has also been shown and other cytostatic mechanisms may also be influenced by dacarbazine [58]. Our unpublished data indicated that dacarbazine was not able to abrogate tumor initiation capabilities thus indicative that is did not target melanoma cancer stem cell population (manuscript under revision).

\section{Off-label use of drugs in melanoma treatment}

Following drugs are, mainly in combination treatment, used in unapproved indications to treat malignant melanoma: temozolimide (prodrug, alkylating agent), cisplatin (alkylating agent), carboplatin (alkylating agent), vinblastine (inhibitor of mitosis), paclitaxel (inhibitor of mitosis), sorafenib (protein kinase inhibitor), imatinib (protein-tyrosine kinase inhibitor), sargramostim (recombinant human granulocyte macrophage colony stimulating factor (rhu GM-CSF)) with ipilimumab $[55,59]$.

\section{Prevention}

Skin should be protected from intense sun exposure by wearing tightly woven clothing and a wide-brimmed hat, applying sunscreen that has a sun protection factor (SPF) of 30 or higher to unprotected skin, seeking shade (especially at midday, when the sun's rays are strongest), and avoiding sunbathing and indoor tanning. Sunglasses should be worn to protect the skin around the eyes. Children should be especially protected from the sun because severe sunburns in childhood may greatly increase the risk of melanoma. Tanning beds and sun lamps, which provide an additional source of UV radiation, can cause skin cancer and should be avoided [60].

\section{Conclusion}

Here we summarized the current knowledge about malignant melanoma risk factors, current approaches to melanoma diagnosis, treatment and melanoma CSCs. Only deep identification of malignant melanoma properties can help to design effective anticancer therapy. Target therapy combined BRAF inhibitor (vemurafenib) plus MEK inhibitor (cobimetinib) confirmed its superior impact on progression-free survival. Although new drugs and expectations have arisen for patients with melanoma in recent years, it is generally still incurable at the stage of metastatic dissemination. The new discovered treatments prolong patient's life, achieve tumor shrinkage and relieve symptoms, but their cost is high. New treatments are not as aggressive as conventional chemotherapy and do not cause hair loss, although they are associated with a wide range of toxicities [49].

New therapeutic strategies that aim to eliminate CSCs by targeting for example CSC-specific CD44 isoform(s) may be developed that will bring new hope to patients with lifethreatening cancer [61].

This strategy together with the gene therapy using genetically modified MSC, which are able to convert nontoxic prodrug to highly toxic chemotherapeutic at the site of the tumor seems to be the anticancer therapy of the near future. Combinations of traditional, targeted and stem cell-directed gene therapy could significantly advance the treatment of cancer [62-66].

Acknowledgements: The studies and experiments mentioned in this study were performed with the kind support provided by the Slovak Research and Development Agency under the contract No. APVV-0230-11 and APVV-0052-12; Slovak Cancer Research Foundation; VEGA grants No. 2/0130/13 (Z.K) and 2/0087/15 (L.K).

\section{References}

[1] HONG WK, RESEARCH AAFC, HAIT WN. Holland Frei Cancer Medicine Eight: People's Medical Publishing House; 2010.

[2] MACKIE RM, FREUDENBERGER T, AITCHISON TC. Personal risk-factor chart for cutaneous melanoma. Lancet. 1989; 2: 487-90. http://dx.doi.org/10.1016/S0140-6736(89)92097-7

[3] MANSON JE, REXRODE KM, GARLAND FC, GARLAND CF, WEINSTOCK MA. The case for a comprehensive national campaign to prevent melanoma and associated mortality. Epidemiology. 2000; 11: 728-34. http://dx.doi. org/10.1097/00001648-200011000-00021

[4] ABBASI NR, SHAW HM, RIGEL DS, FRIEDMAN RJ, MCCARTHY WH, et al. Early diagnosis of cutaneous melanoma: revisiting the ABCD criteria. JAMA. 2004; 292: 2771-6. http:// dx.doi.org/10.1001/jama.292.22.2771

[5] RIGEL DS, FRIEDMAN RJ, KOPF AW, POLSKY D. ABCDE-an evolving concept in the early detection of melanoma. Arch Dermatol. 2005; 141: 1032-4. http://dx.doi.org/10.1001/ archderm.141.8.1032

[6] BALCH CM, GERSHENWALD JE, SOONG SJ, THOMPSON JF, ATKINS MB, et al. Final version of 2009 AJCC melanoma staging and classification. J Clin Oncol. 2009; 27: 6199-206. http://dx.doi.org/10.1200/JCO.2009.23.4799

[7] ROSKOSKI R, JR. RAF protein-serine/threonine kinases: structure and regulation. Biochem Biophys Res Commun. 2010; 399: 313-7. http://dx.doi.org/10.1016/j. bbrc.2010.07.092 
[8] BERGER MF, HODIS E, HEFFERNAN TP, DERIBE YL, LAWRENCE MS, et al. Melanoma genome sequencing reveals frequent PREX2 mutations. Nature. 2012; 485: 502-6. http:// dx.doi.org/10.1038/nature11071

[9] HODIS E, WATSON IR, KRYUKOV GV, AROLD ST, IMIELINSKI $\mathrm{M}$, et al. A landscape of driver mutations in melanoma. Cell. 2012; 150: 251-63. http://dx.doi. org/10.1016/j.cell.2012.06.024

[10] KRAUTHAMMER M, KONG Y, HA BH, EVANS P, BACCHIOCCHI A, et al. Exome sequencing identifies recurrent somatic RAC1 mutations in melanoma. Nat Genet. 2012; 44: 1006-14. http://dx.doi.org/10.1038/ng.2359

[11] DAVIES H, BIGNELL GR, COX C, STEPHENS P, EDKINS $S$, et al. Mutations of the BRAF gene in human cancer. Nature. 2002; 417: 949-54. http://dx.doi.org/10.1038/nature00766

[12] KORN EL, LIU PY, LEE SJ, CHAPMAN JA, NIEDZWIECKI $\mathrm{D}$, et al. Meta-analysis of phase II cooperative group trials in metastatic stage IV melanoma to determine progression-free and overall survival benchmarks for future phase II trials. J Clin Oncol. 2008; 26: 527-34. http://dx.doi.org/10.1200/ LCO.2007.12.7837

[13] MCARTHUR GA, CHAPMAN PB, ROBERT C, LARKIN J, HAANEN JB, et al. Safety and efficacy of vemurafenib in BRAF(V600E) and BRAF(V600K) mutation-positive melanoma (BRIM-3): extended follow-up of a phase 3, randomised, open-label study. Lancet Oncol. 2014; 15: 323-32. http://dx.doi.org/10.1016/S1470-2045(14)70012-9

[14] HAUSCHILD A, GROB JJ, DEMIDOV LV, JOUARY T, GUTZMER R, et al. Dabrafenib in BRAF-mutated metastatic melanoma: a multicentre, open-label, phase 3 randomised controlled trial. Lancet. 2012; 380: 358-65. http://dx.doi. org/10.1016/S0140-6736(12)60868-X

[15] HOPE KJ, JIN L, DICK JE. Acute myeloid leukemia originates from a hierarchy of leukemic stem cell classes that differ in self-renewal capacity. Nat Immunol. 2004; 5: 738-43. http:// dx.doi.org/10.1038/ni1080

[16] FABIAN A, VEREB G, SZOLLOSI J. The Hitchhikers Guide to Cancer Stem Cell Theory: Markers, Pathways and Therapy. Cytometry Part A. 2013; 83A: 62-71. http://dx.doi. org/10.1002/cyto.a.22206

[17] WARD RJ, DIRKS PB. Cancer stem cells: at the headwaters of tumor development. Annu Rev Pathol. 2007; 2: 175-89. http://dx.doi.org/10.1146/annurev.pathol.2.010506.091847

[18] HANAHAN D, WEINBERG RA. Hallmarks of cancer: the next generation. Cell. 2011; 144: 646-74. http://dx.doi. org/10.1016/j.cell.2011.02.013

[19] LU Y, MAHATO RI. Pharmaceutical Perspectives of Cancer Therapeutics: Springer New York; 2009.

[20] REYA T, MORRISON SJ, CLARKE MF, WEISSMAN IL. Stem cells, cancer, and cancer stem cells. Nature. 2001; 414: 105-11. http://dx.doi.org/10.1038/35102167

[21] PARDAL R, CLARKE MF, MORRISON SJ. Applying the principles of stem-cell biology to cancer. Nature Reviews Cancer. 2003; 3: 895-902. http://dx.doi.org/10.1038/nrc1232

[22] KOZOVSKA Z, GABRISOVA V, KUCEROVA L. Colon cancer: cancer stem cells markers, drug resistance and treat- ment. Biomed Pharmacother. 2014; 68: 911-6. http://dx.doi. org/10.1016/j.biopha.2014.10.019

[23] LAPIDOT T, SIRARD C, VORMOOR J, MURDOCH B, HOANG T, et al. A Cell Initiating Human Acute MyeloidLeukemia after Transplantation into Scid Mice. Nature. 1994; 367: 645-8. http://dx.doi.org/10.1038/367645a 0

[24] FRIEDMANN-MORVINSKI D, VERMA IM. Dedifferentiation and reprogramming: origins of cancer stem cells. Embo Reports. 2014; 15: 244-53. http://dx.doi.org/10.1002/ embr.201338254

[25] GIROUARD SD, MURPHY GF. Melanoma stem cells: not rare, but well done. Lab Invest. 2011; 91: 647-64. http://dx.doi. org/10.1038/labinvest.2011.50

[26] FANG D, NGUYEN TK, LEISHEAR K, FINKO R, KULP AN, et al. A tumorigenic subpopulation with stem cell properties in melanomas. Cancer Res. 2005; 65: 9328-37. http:// dx.doi.org/10.1158/0008-5472.CAN-05-1343

[27] MONZANI E, FACCHETTI F, GALMOZZI E, CORSINI E, BENETTI A, et al. Melanoma contains CD133 and ABCG2 positive cells with enhanced tumorigenic potential. Eur J Cancer. 2007; 43: 935-46. http://dx.doi.org/10.1016/j. ejca.2007.01.017

[28] SCHATTON T, MURPHY GF, FRANK NY, YAMAURA K, WAAGA-GASSER AM, et al. Identification of cells initiating human melanomas. Nature. 2008; 451: 345-9. http://dx.doi. org/10.1038/nature06489

[29] BOIKO AD, RAZORENOVA OV, VAN DE RIJN M, SWETTER SM, JOHNSON DL, et al. Human melanoma-initiating cells express neural crest nerve growth factor receptor CD271. Nature. 2010; 466: 133-7. http://dx.doi.org/10.1038/nature09161

[30] BOONYARATANAKORNKIT JB, YUE L, STRACHAN LR, SCALAPINO KJ, LEBOIT PE, et al. Selection of tumorigenic melanoma cells using ALDH. J Invest Dermatol. 2010; 130: 2799-808. http://dx.doi.org/10.1038/jid.2010.237

[31] FRANK NY, MARGARYAN A, HUANG Y, SCHATTON T, WAAGA-GASSER AM, et al. ABCB5-mediated doxorubicin transport and chemoresistance in human malignant melanoma. Cancer Research. 2005; 65: 4320-33. http://dx.doi. org/10.1158/0008-5472.CAN-04-3327

[32] CIVENNI G, WALTER A, KOBERT N, MIHIC-PROBST D, ZIPSER M, et al. Human CD271-Positive Melanoma Stem Cells Associated with Metastasis Establish Tumor Heterogeneity and Long-term Growth. Cancer Research. 2011; 71: 3098-109. http://dx.doi.org/10.1158/0008-5472.CAN-10-3997

[33] LUO YC, DALLAGLIO K, CHEN Y, ROBINSON WA, ROBINSON SE, et al. ALDH1A Isozymes are Markers of Human Melanoma Stem Cells and Potential Therapeutic Targets. Stem Cells. 2012; 30: 2100-13. http://dx.doi.org/10.1002/ $\underline{\text { stem. } 1193}$

[34] AGUILERA O, GONZALEZ-SANCHO JM, ZAZO S, RINCON R, FERNANDEZ AF, et al. Nuclear DICKKOPF-1 as a biomarker of chemoresistance and poor clinical outcome in colorectal cancer. Oncotarget. 2015; 6: 5903-17. http://dx.doi. org/10.18632/oncotarget.3464

[35] WANG K, CHEN X, ZHAN Y, JIANG W, LIU X, et al. Increased expression of ALDH1A1 protein is associated 
with poor prognosis in clear cell renal cell carcinoma. Med Oncol. 2013; 30: 574. http://dx.doi.org/10.1007/s12032-013 -0574-Z

[36] KHOURY T, ADEMUYIWA FO, CHANDRASEKHAR R, JABBOUR M, DELEO A, et al. Aldehyde dehydrogenase $1 \mathrm{~A} 1$ expression in breast cancer is associated with stage, triple negativity, and outcome to neoadjuvant chemotherapy. Mod Pathol. 2012; 25: 388-97. http://dx.doi.org/10.1038/ modpathol.2011.172

[37] LANDEN CN, Jr., GOODMAN B, KATRE AA, STEG AD, NICK AM, et al. Targeting aldehyde dehydrogenase cancer stem cells in ovarian cancer. Mol Cancer Ther. 2010; 9: 318699. http://dx.doi.org/10.1158/1535-7163.MCT-10-0563

[38] DUONG HQ, HWANG JS, KIM HJ, KANG HJ, SEONG YS, et al. Aldehyde dehydrogenase $1 \mathrm{~A} 1$ confers intrinsic and acquired resistance to gemcitabine in human pancreatic adenocarcinoma MIA PaCa-2 cells. Int J Oncol. 2012; 41: 855-61.

[39] ZHI QM, CHEN XH, JI J, ZHANG JN, LI JF, et al. Salinomycin can effectively kill ALDH(high) stem-like cells on gastric cancer. Biomed Pharmacother. 2011; 65: 509-15. http://dx.doi. org/10.1016/j.biopha.2011.06.006

[40] ROESCH A, VULTUR A, BOGESKI I, WANG H, ZIMMERMANN KM, et al. Overcoming intrinsic multidrug resistance in melanoma by blocking the mitochondrial respiratory chain of slow-cycling JARID1B(high) cells. Cancer Cell. 2013; 23: 811-25. http://dx.doi.org/10.1016/j.ccr.2013.05.003

[41] MITRA A, MISHRA L, LI S. EMT, CTCs and CSCs in tumor relapse and drug-resistance. Oncotarget. 2015; 6: 10697-711. http://dx.doi.org/10.18632/oncotarget.4037

[42] ITO K, SUDA T. Metabolic requirements for the maintenance of self-renewing stem cells. Nat Rev Mol Cell Biol. 2014; 15: 243-56. http://dx.doi.org/10.1038/nrm3772

[43] ROESCH A. Melanoma stem cells. J Dtsch Dermatol Ges. 2015; 13: 118-24. http://dx.doi.org/10.1111/ddg. 12584

[44] SALTMAN BE, GANLY I, PATEL SG, COIT DG, BRADY MS, et al. Prognostic implication of sentinel lymph node biopsy in cutaneous head and neck melanoma. Head Neck. 2010; 32: 1686-92. http://dx.doi.org/10.1002/hed.21390

[45] DAY CL, Jr., MIHM MC, Jr., LEW RA, HARRIS MN, KOPF AW, et al. Prognostic factors for patients with clinical stage I melanoma of intermediate thickness $(1.51-3.39 \mathrm{~mm})$. A conceptual model for tumor growth and metastasis. Ann Surg. 1982; 195: 35-43. http://dx.doi.org/10.1097/00000658198201001-00006

[46] HOFMANN MA, STERRY W, TREFZER U. Complex combination biochemotherapy regimen in advanced metastatic melanoma in a non-intensive care unit: toxicity or benefit? Jpn J Clin Oncol. 2007; 37: 224-9. http://dx.doi.org/10.1093/ jico/hym009

[47] ROTTE A, BHANDARU M, ZHOU Y, MCELWEE K. Immunotherapy of melanoma: Present options and future promises. Cancer and Metastasis Reviews. 2015; 34: 115-28. http://dx.doi.org/10.1007/s10555-014-9542-0

[48] MOZZILLO N, ASCIERTO P. Reduction of circulating regulatory $\mathrm{T}$ cells by intravenous high-dose interferon alfa$2 \mathrm{~b}$ treatment in melanoma patients. Clin Exp Metastasis.
2012; 29: 801-5. http://dx.doi.org/10.1007/s10585-0129504-2

[49] FOLETTO MC, HAAS SE. Cutaneous melanoma: new advances in treatment. An Bras Dermatol. 2014; 89: 301-10. http://dx.doi.org/10.1590/abd1806-4841.20142540

[50] SWAIKA A, CROZIER JA, JOSEPH RW. Vemurafenib: an evidence-based review of its clinical utility in the treatment of metastatic melanoma. Drug Des Devel Ther. 2014; 8: 775-87.

[51] FALCHOOK GS, LONG GV, KURZROCK R, KIM KB, ARKENAU TH, et al. Dabrafenib in patients with melanoma, untreated brain metastases, and other solid tumors: a phase 1 dose-escalation trial. Lancet. 2012; 379: 1893-901. http:// dx.doi.org/10.1016/S0140-6736(12)60398-5

[52] SARANGA-PERRY V, AMBE C, ZAGER JS, KUDCHADKAR RR. Recent developments in the medical and surgical treatment of melanoma. CA: A Cancer Journal for Clinicians. 2014; 64: 171-85. http://dx.doi.org/10.3322/caac.21224

[53] HAASS NK, SPROESSER K, NGUYEN TK, CONTRACTOR $\mathrm{R}, \mathrm{MEDINA} C A$, et al. The mitogen-activated protein/extracellular signal-regulated kinase kinase inhibitor AZD6244 (ARRY-142886) induces growth arrest in melanoma cells and tumor regression when combined with docetaxel. Clin Cancer Res. 2008; 14: 230-9. http://dx.doi.org/10.1158/1078-0432. CCR-07-1440

[54] NIEZGODA A, NIEZGODA P, CZAJKOWSKI R. Novel Approaches to Treatment of Advanced Melanoma: A Review on Targeted Therapy and Immunotherapy. Biomed Res Int. 2015; 2015: 851387. http://dx.doi.org/10.1155/2015/851387

[55] LIPSON EJ, DRAKE CG. Ipilimumab: An Anti-CTLA-4 Antibody for Metastatic Melanoma. Clinical Cancer Research. 2011; 17: 6958-62. http://dx.doi.org/10.1158/1078-0432.CCR11-1595

[56] CAMACHO LH, ANTONIA S, SOSMAN J, KIRKWOOD JM, GAJEWSKI TF, et al. Phase I/II trial of tremelimumab in patients with metastatic melanoma. J Clin Oncol. 2009; 27: 1075-81. http://dx.doi.org/10.1200/JCO.2008.19.2435

[57] KHOJA L, BUTLER MO, KANG SP, EBBINGHAUS S, JOSHUA AM. Pembrolizumab. J Immunother Cancer. 2015; 3: 36. http://dx.doi.org/10.1186/s40425-015-0078-9

[58] CHENG Y, ZHANG G, LI G. Targeting MAPK pathway in melanoma therapy. Cancer and Metastasis Reviews. 2013; 32: 567-84. http://dx.doi.org/10.1007/s10555-013-9433-9

[59] LUKE JJ, DONAHUE H, NISHINO M, GIOBBIE-HURDER A, DAVIS M, et al. Single Institution Experience of Ipilimumab $3 \mathrm{mg} / \mathrm{kg}$ with Sargramostim (GM-CSF) in Metastatic Melanoma. Cancer Immunology Research. 2015; 3: 986-91. http://dx.doi.org/10.1158/2326-6066.CIR-15-0066

[60] SOCIETY AC. Cancer Facts \& Figures 2015. Atlanta: American Cancer Society.2015. p. 1-52.

[61] YAN Y, ZUO X, WEI D. Concise Review: Emerging Role of CD44 in Cancer Stem Cells: A Promising Biomarker and Therapeutic Target. Stem Cells Transl Med. 2015; 4: 1033-43. http://dx.doi.org/10.5966/sctm.2015-0048

[62] HONG IS, LEE HY, KANG KS. Mesenchymal stem cells and cancer: friends or enemies? Mutat Res. 2014; 768: 98-106. http://dx.doi.org/10.1016/j.mrfmmm.2014.01.006 
[63] DURINIKOVA E, KUCEROVA L, MATUSKOVA M. Mesenchymal stromal cells retrovirally transduced with prodrug-converting genes are suitable vehicles for cancer gene therapy. Acta Virol. 2014; 58: 1-13. http://dx.doi.org/10.4149/ av 2014013

[64] KUCEROVA L, ALTANEROVA V, MATUSKOVA M, TYCIAKOVA S, ALTANER C. Adipose tissue-derived human mesenchymal stem cells mediated prodrug cancer gene therapy. Cancer Res. 2007; 67: 6304-13. http://dx.doi. org/10.1158/0008-5472.CAN-06-4024

[65] KUCEROVA L, MATUSKOVA M, PASTORAKOVA A, TYCIAKOVA S, JAKUBIKOVA J, et al. Cytosine deaminase expressing human mesenchymal stem cells mediated tumor regression in melanoma bearing mice. J Gene Med. 2008; 10: 1071-82. http://dx.doi.org/10.1002/jgm.1239

[66] BOHOVIC R, DEMKOVA L, CIHOVA M, SKOLEKOVA S, DURINIKOVA E, et al. 3D multicellular models reflect the efficiency of MSC-directed enzyme/prodrug treatment. Neoplasma. 2015; 62: 521-30. http://dx.doi.org/10.4149/neo 2015063

[67] DUMMER R, HAUSCHILD A, LINDENBLATT N, PENTHEROUDAKIS G, KEILHOLZ U. Cutaneous melanoma: ESMO Clinical Practice Guidelines for diagnosis, treatment and follow-up. Annals of Oncology. 2015; 26:v126-v32. http:// dx.doi.org/10.1093/annonc/mdv297 